\title{
ICU Complications of Hematopoietic Stem Cell Transplant, Including Graft vs Host Disease
}

\author{
R. Scott Stephens
}

\section{Case Presentation}

A 44 year-old woman with a history of acute myeloid leukemia (AML) underwent a non-myeloablative haploidentical peripheral blood hematopoietic stem cell transplant (HSCT) 10 days ago. She was admitted to the hospital with fevers to $39{ }^{\circ} \mathrm{C}$. On examination, she is anxious-appearing, with a temperature of $38.9^{\circ} \mathrm{C}$, a heart rate of 120 beats/min, a respiratory rate of 28 breaths $/ \mathrm{min}$, a blood pressure of $98 / 64 \mathrm{mmHg}$, and an oxygen saturation of $94 \%$ on $4 \mathrm{~L} / \mathrm{min}$ oxygen via nasal cannula. A tunneled central venous catheter is in situ in her right internal jugular vein. Her total white blood cell (WBC) count is $<0.5$ cells $/ \mathrm{mm}^{3}$ and platelet count is 8000 cells $/ \mathrm{mm}^{3}$. A chest CT scan shows diffuse patchy bilateral infiltrates (Figure). She is started on empiric antibiotic coverage with piperacillin/tazobactam, and $3 \mathrm{~L}$ of crystalloid are administered. Several hours later, she is more hypotensive, with nadir systolic pressures of $80-88 \mathrm{mmHg}$, and is more hypoxic, now saturating $85 \%$ on $6 \mathrm{~L} / \mathrm{min}$ nasal cannula oxygen.

\section{Question}

How should this patient be managed?

Answer Broad spectrum antibiotics and lung-protective respiratory support.

All patients after HSCT are immunosuppressed, profoundly so in the early post-transplant period before engraftment has occurred. This patient is likely to have a pneumonia with secondary septic shock, but a central line-associated infection from her tunneled central line is possible, as are

\footnotetext{
R. S. Stephens $(\bowtie)$

Oncology and Bone Marrow Transplant Critical Care, Division of Pulmonary and Critical Care Medicine, Departments of Medicine and Oncology, Johns Hopkins University, Baltimore, MD, USA e-mail: rsteph13@jhmi.edu
}

non-infectious complications of HSCT. Respiratory failure is the most frequent cause of intensive care unit (ICU) admission after HSCT, most frequently from an infectious cause. The patient was placed on high-flow nasal cannula (HFNC) for oxygenation support and started on a norepinephrine infusion for hemodynamic support. Antibacterial coverage was changed to meropenem, levofloxacin, and vancomycin, and voriconazole was added for antifungal coverage. Her central line was removed. Her respiratory status continued to decline, and endotracheal intubation and mechanical ventilation were required $24 \mathrm{~h}$ after admission. She was placed on volume assist-control with a tidal volume of $6 \mathrm{~mL} / \mathrm{kg}$ predicted body weight, and bronchoscopy with bronchoalveolar lavage (BAL) was performed. The BAL fluid was initially bloody, but cleared with sequential aliquots. Microbiologic studies of the BAL fluid were positive for respiratory syncytial virus and Pseudomonas aeruginosa. She was maintained on low tidal-volume ventilation and vasopressors were weaned off. Her white blood cell count slowly began to recover, and her respiratory status began to improve. She was extubated on hospital day 12 and was discharged from the ICU on hospital day 14.

\section{Principles of Management}

Hematopoietic stem cell transplant (HSCT) has become an essential therapeutic modality in the treatment of malignant and non-malignant hematologic disease. In 2016, more than 23,000 HSCTs were performed in the United States, including approximately 15,000 autologous HSCTs and more than 8500 allogeneic transplants [1]. Allogeneic transplants are associated with more morbidity and mortality than autologous transplants, and are further categorized based on conditioning regimen (myeloablative [MA] vs non-myeloablative [NMA]), donor-recipient relation (related vs unrelated), HLA matching (full match vs haploidentical vs mismatched), and stem cell source (bone marrow, peripheral blood, 
umbilical cord blood). In general, NMA regimens are associated with less peri-transplant morbidity and mortality than fully ablative transplants. In both MA and NMA transplants, the cytotoxic conditioning regimen required in HSCT rapidly induces neutropenia by injuring hematopoietic precursor cells within the bone marrow [2,3]. Neutropenia persists until donor cell engraftment or bone marrow recovery. The period of aplasia and neutropenia places the HSCT patient at high risk for infectious complications. In addition to the lack of immune cells, the mucosal barrier of the intestinal tract is disrupted by chemotherapy, creating portals through which enteric pathogens can enter the bloodstream [4-6]. The respiratory system is also more susceptible to infection, with qualitative and quantitative dysfunction of alveolar macrophages, lymphocytes, and neutrophils [7-9]. Even after the marrow and mucosal surfaces have recovered, the immunological consequences of HSCT can cause further complications requiring critical care. Refinement of transplant techniques over the last 2 decades has dramatically decreased transplant-related mortality, but approximately $15 \%$ of HSCT patients require critical care [10] and earlier ICU admission has been associated with improved survival rates $[11,12]$. Still, ICU mortality in allogeneic HSCT patients remains approximately $50 \%$ [13].

\section{Early Complications of Hematopoietic Stem Cell Transplant}

The early complications of HSCT (day 30-100) are predominantly infectious in nature, and patients typically present to the ICU with septic shock or respiratory failure. The latter is the most common reason for ICU admission after HSCT [10]. Non-infectious complications also occur, and can involve nearly any organ system.

\section{Neutropenic Fever and Neutropenic Sepsis}

Neutropenic fever, defined as any fever higher than $38.3^{\circ} \mathrm{C}$ or a sustained fever greater than $38.0^{\circ} \mathrm{C}$ for more than $1 \mathrm{~h}$ with an absolute neutrophil count (ANC) less than 1500 cells/ $\mathrm{mm}^{3}$, occurs in more than $80 \%$ of patients undergoing HSCT $[14,15]$. No organism is identified in about $50 \%$ of neutropenic fevers $[14,15]$. Bacteremia is documented in up to $25 \%$ of patients. Gram-positive bacteria are most commonly isolated $[14,16]$ (Table 80.1), while Gram-negative infections confer a higher mortality risk [17]. Fungal infections, particularly Candida and Aspergillus species, are frequent, especially in prolonged or profound neutropenia [15]. Approximately $10 \%$ of allogeneic HSCT patients will develop severe sepsis during the engraftment period [18], and mortality is approximately $50 \%$ in those who go on to develop septic shock [11,
Table 80.1 Typical pathogens and origins during bacterial sepsis in neutropenic patients [Adapted from [21] (Springer)]

\begin{tabular}{|c|c|}
\hline Origin & Frequent pathogens \\
\hline Unknown & $\begin{array}{l}\text { Coagulase-negative Staphylococci, Escherichia coli, } \\
\text { Enterococcus species }\end{array}$ \\
\hline Lung & $\begin{array}{l}\text { Pseudomonas aeruginosa, Streptococcus pneumonia, } \\
\text { Viridans streptococci, Acinetobacter species }\end{array}$ \\
\hline Abdomen & $\begin{array}{l}\text { Escherichia coli, Pseudomonas aeruginosa, } \\
\text { Clostridium species, Enterococcus species, Klebsiella } \\
\text { species }\end{array}$ \\
\hline Urogenital & $\begin{array}{l}\text { Escherichia coli, Pseudomonas aeruginosa, } \\
\text { Klebsiella species }\end{array}$ \\
\hline Soft tissue & Staphylococcus aureus, alpha-hemolytic streptococci \\
\hline $\begin{array}{l}\text { Central } \\
\text { venous } \\
\text { catheter }\end{array}$ & $\begin{array}{l}\text { Coagulase-negative Staphylococci, Coryneform } \\
\text { bacteria, propionibacterium species, Candida } \\
\text { albicans, Candida tropicalis, Candida parapsilosis, } \\
\text { Stenotrophomonas maltophilia }\end{array}$ \\
\hline
\end{tabular}

19, 20]. Mortality predictors include concomitant graft-vshost disease (GVHD), respiratory failure, positive blood cultures, and multi-organ failure [18, 20].

Neutropenic fever and sepsis are medical emergencies, and appropriate empiric antibiotics must be started without delay: ideally within 60 min of presentation $[14,15,21]$ and potentially within $30 \mathrm{~min}$ [22]. Empiric antibiotics must cover common organisms and should be tailored to patientspecific culture data and institutional epidemiology $[14,15]$. Appropriate empiric antibiotics include an anti-pseudomonal penicillin or cephalosporin (e.g. piperacillin/tazobactam or cefepime, respectively), or a carbapenem [14, 15]. Vancomycin is not routinely indicated but should be added in the presence of a suspected catheter-related infection, soft tissue infection, oral mucositis, pneumonia, known colonization with resistant gram-positive organisms, or hemodynamic instability [14, 15, 21]. Aminoglycosides should not be added to an anti-pseudomonal beta-lactam unless required by allergies, resistant organisms, or refractory hemodynamic instability [14, 21, 23-25]. Fluoroquinolones, which are frequently used as prophylaxis in HSCT patients, should not be used as empiric monotherapy due to the likelihood of resistance.

In hemodynamically unstable patients, anti-pseudomonal beta-lactams should be escalated to a carbapenem and consideration should be given to the addition of an aminoglycoside or aztreonam [14, 15, 21, 23]. Vancomycin should be added if not already part of the regimen, and anti-fungals with activity against yeasts and molds (e.g. liposomal amphotericin, caspofungin, or voriconazole) should be strongly considered in all unstable patients [14, 15, 26, 27].

Identification of infectious organisms and control of infectious sources are essential to optimize outcomes but the infectious workup should not delay antibiotic administration. Blood cultures and respiratory cultures should be obtained and sinus, head, chest, and abdominal imaging performed as indicated [14, 15]. Abdominal pain or diarrhea 
associated with fever suggests neutropenic enterocolitis (typhlitis) which can lead to intestinal necrosis [28, 29]. In the hemodynamically unstable patient with a central venous catheter, early catheter removal is associated with improved survival [19]; infected or potentially infected catheters should be removed without delay.

\section{Respiratory Failure}

Acute respiratory failure and acute respiratory distress syndrome (ARDS) are major problems after HSCT [30, 31]. Data from the 1990s indicated that $40-60 \%$ of patients undergoing HSCT experience a respiratory complication [32]. More recent data suggest that more than $15 \%$ of patients undergoing allogeneic transplant develop ARDS with a mortality rate of 50-70\% [33, 34]. Most cases of respiratory failure and ARDS after HSCT are related to infection, either a primary pulmonary infection or sepsis [35]. Common pulmonary infections and associated risk factors are shown in Table 80.2. Respiratory viral infection is common after

Table 80.2 Common pulmonary infections after HSCT

\begin{tabular}{|c|c|c|c|}
\hline Infection & Common pathogens & $\begin{array}{l}\text { Risk factors for } \\
\text { occurrence and } \\
\text { severity }\end{array}$ & Reference \\
\hline Bacterial & $\begin{array}{l}\text { Streptococcus } \\
\text { pneumonia } \\
\text { Streptococcus viridans } \\
\text { Staphylococcus aureus } \\
\text { Pseudomonas } \\
\text { aeruginosa } \\
\text { Acinetobacter } \\
\text { Stenotrophomonas } \\
\text { maltophilia } \\
\text { Nocardia asteroides }\end{array}$ & $\begin{array}{l}\text { Neutropenia } \\
\text { Oral mucositis } \\
\text { Aspiration } \\
\text { Antecedent viral } \\
\text { pneumonia }\end{array}$ & {$[35]$} \\
\hline Viral & $\begin{array}{l}\text { Influenza } \\
\text { Adenovirus } \\
\text { Respiratory syncytial } \\
\text { virusrhinovirus } \\
\text { Parainfluenza } \\
\text { Human } \\
\text { metapneumovirus } \\
\text { Cytomegalovirus }\end{array}$ & $\begin{array}{l}\text { Neutropenia } \\
\text { Lymphopenia } \\
\text { Allogeneic } \\
\text { transplant } \\
\text { Bone marrow graft } \\
\text { source } \\
\text { Steroid therapy } \\
\text { Infection } \\
\text { pre-engraftment } \\
\text { Presence of } \\
\text { co-pathogens } \\
\text { Older age } \\
\text { GVHD }\end{array}$ & $\begin{array}{l}{[35,} \\
37-39]\end{array}$ \\
\hline Fungal & $\begin{array}{l}\text { Aspergillus species } \\
\text { Pneumocystis jiroveci } \\
\text { Mucorales (e.g. } \\
\text { Rhizopus, Mucor) } \\
\text { Fusarium species } \\
\text { Histoplasma } \\
\text { capsulatum } \\
\text { Coccidioides immitis } \\
\text { Blastomyces } \\
\text { dermatitidis }\end{array}$ & $\begin{array}{l}\text { Prolonged } \\
\text { neutropenia } \\
\text { Lymphopenia } \\
\text { Steroids } \\
\text { GVHD } \\
\text { Geographic } \\
\text { exposure } \\
\text { Residential exposure }\end{array}$ & {$[35,42]$} \\
\hline
\end{tabular}

HSCT [36, 37], and is associated with significant mortality, especially with progression to lower respiratory tract infection [38-40]. In some cases, antiviral therapy with agents such as oseltamivir (influenza) or ribavirin (respiratory syncytial virus) is indicated [41]. Bacterial pneumonias are also common and may occur as a co-infection or secondary infection with a respiratory virus. Fungal and other opportunistic infections such as Pneumocystis jirovecii must also be considered [42]. As in immunocompetent patients, treatment of ARDS centers on treatment of the underlying cause while providing supportive care with low tidal volume mechanical ventilation. Neuromuscular blockade and prone positioning should be considered in patients with an arterial $\mathrm{PO}_{2}$ : $\mathrm{FiO}_{2} \leq 150 \mathrm{mmHg}$ [43-45].

Non-invasive ventilation (NIV) is frequently used as firstline respiratory support in HSCT patients [46]. However, early studies which showed a mortality benefit in immunosuppressed patients with using NIV compared to invasive mechanical ventilation were limited by relatively few numbers of HSCT patients and extremely high mortality in the control groups [47, 48]. It is nearly impossible to control delivered tidal volume with NIV and high delivered noninvasive tidal volumes are linked to higher rates of NIV failure [49]. More recent data suggest that NIV may not be beneficial in HSCT patients and heated humidified high-flow oxygen may be a better option [30, 49-53].

Chest computed tomography (CT) scanning should be performed in all patients with respiratory symptoms [15]. The presence of respiratory failure, respiratory symptoms, or abnormalities on chest imaging should prompt evaluation for a respiratory infection. In many cases a non-invasive evaluation is appropriate, but bronchoscopy may be indicated in some patients $[48,54,55]$, and bronchoscopic findings that lead to a change in management are associated with improved outcomes [55].

Two specific forms of respiratory failure after HSCT warrant special mention: diffuse alveolar hemorrhage and idiopathic pneumonia syndrome. Diffuse alveolar hemorrhage (DAH) occurs in up to $12 \%$ of patients and is associate with poor outcomes $[56,57]$. Diagnosis is most commonly made by observation of progressively bloody aliquots of bronchoalveolar lavage. Steroids are the mainstay of treatment of $\mathrm{DAH}$, with some evidence that efficacy is greatest at doses $<250 \mathrm{mg} /$ day of methylprednisolone equivalent [57]. Idiopathic pneumonia syndrome (IPS) is a form of noninfectious lung injury after HSCT and is clinically defined by diffuse alveolar injury when infection, cardiac dysfunction, renal failure, and volume overload have been excluded [58]. IPS can have many manifestations, including ARDS, pulmonary capillary leak, DAH, or cryptogenic organizing pneumonia. IPS is thought to affect up to $15 \%$ of patients after myeloablative allogeneic HSCT, and only $\sim 2 \%$ of patients after non-myeloablative HSCT. Median time of onset of IPS 
is 19 days after HSCT and mortality ranges from $60-80 \%$ in all patients, with nearly $100 \%$ mortality if mechanical ventilation is required [58]. Though the pathophysiology of IPS is incompletely understood, research indicating a pathogenic role for TNF- $\alpha$ has led to the use of the anti-TNF- $\alpha$ antibody etanercept to treat IPS, with mixed clinical results [59-62]. The single randomized placebo-controlled trial in adults included only 34 patients and showed no benefit to etanercept when added to steroids (methylprednisolone $2 \mathrm{mg} / \mathrm{kg}$ / day) [63].

\section{Neurologic Complications}

Neurologic complications are frequently encountered after HSCT [64]. Intracerebral hemorrhages are a constant threat in thrombocytopenic patients. Infections of the central nervous system (CNS), including viral, bacterial, and fungal, can occur, and may require modification of antibiotic regimens to ensure CNS penetration. Seizures and generalized encephalopathy can occur, often with cryptic causes. Posterior reversible encephalopathy syndrome (PRES) is increasingly recognized, especially in patients receiving tacrolimus-based GVHD prophylaxis. Any of these complications may be life-threatening, and close collaboration with neurology and neurocritical care specialists may be required.

\section{Acute Kidney Injury}

Acute kidney injury (AKI) is common after HSCT and affects up to $40 \%$ of patients, with higher incidence after allogeneic transplant than autologous transplant $[65,66]$. In addition to the usual ICU causes of AKI such as septic shock, there are many specific contributors to the risk of AKI in HSCT, including preparative chemotherapeutic regimens, nephrotoxins (e.g. tacrolimus, cyclosporine, antimicrobials), elevated cytokine levels, GVHD, and hepatic sinusoidal obstruction [65]. Hemorrhagic cystitis arising from chemotherapy toxicity or viral infection can cause significant blood loss and obstructive nephropathy due to blood clots. Management of AKI primarily consists of limiting exposure to nephrotoxins (if able) and maintaining adequate hemodynamics. If hemorrhagic cystitis is present, continuous bladder irrigation with a three-way catheter should be considered. The requirement for renal replacement therapy is ominous and portends a high mortality rate [65].

\section{Hepatic Veno-Occlusive Disease}

Hepatic veno-occlusive disease (VOD), also known as sinusoidal obstruction syndrome, primarily occurs after myeloablative HSCT, but can occur after a non-myeloablative transplant [67]. VOD is thought to be caused by damage to the hepatic endothelium and leads to obliteration of hepatic sinusoids and hepatocyte necrosis. Incidence of VOD is thought to be approximately $14 \%$, though estimates vary. Diagnosis is based on clinical findings (table) including hepatomegaly, elevated bilirubin ascites, and weight gain [68]. There are limited therapeutic options for VOD, and the prognosis is poor.

\section{Acute Graft-Versus-Host Disease}

A major complication of allogeneic HSCT is graft-versushost disease (GVHD), which is divided into acute and chronic forms. Acute GVHD is a major contributor to peritransplant morbidity and mortality, and is caused by donororigin T-cells recognizing recipient tissues as foreign and instigating an immune response against the transplant recipient [69]. Acute GVHD generally occurs within the first 100 days after transplant and can affect the skin, mucosa, intestinal tract, and liver. Grading is based on severity of clinical manifestations, which include skin erythema or maculopapular rash; nausea, emesis, or diarrhea, and elevated bilirubin levels (Fig. 80.1, Table 80.3) [69-72]. Acute GVHD can progress to frank epidermal desquamation, massive diarrhea and hematochezia, and fulminant liver failure, respectively. Severe skin acute GVHD behaves much like a burn injury, and the expertise of a burn center may be required. Corticosteroids are the mainstay of treatment for acute GVHD, and the prognosis of steroid-refractory disease is poor [69, 73]. Prophylaxis against GVHD is an essential part of allogeneic transplant regimens and includes a variety of modalities, including calcinuerin inhibitors, anti-metabolites, and post-transplant cyclophosphamide [74]. As GVHD prophylaxis has improved, more patients are presenting with Grade II or Grade III acute GVHD (and fewer are presenting with Grade IV acute GVHD), the incidence of hepatic acute GVHD is decreasing, and overall mortality from acute GVHD is decreasing in patients treated with tacrolimusbased GVHD prophylaxis [73].

\section{Chronic Graft vs Host Disease}

Chronic GVHD is the major cause of non-relapse-related mortality after HSCT [75]. Despite its name, chronic GVHD is defined clinically, rather than by time after transplant, and can present at any time during the transplant course. By 2 years after transplant, up to $30-70 \%$ of patients will have some manifestation of chronic GVHD [76-78]. Though the biology of chronic GVHD is complex and incompletely understood, clinically it mimics 

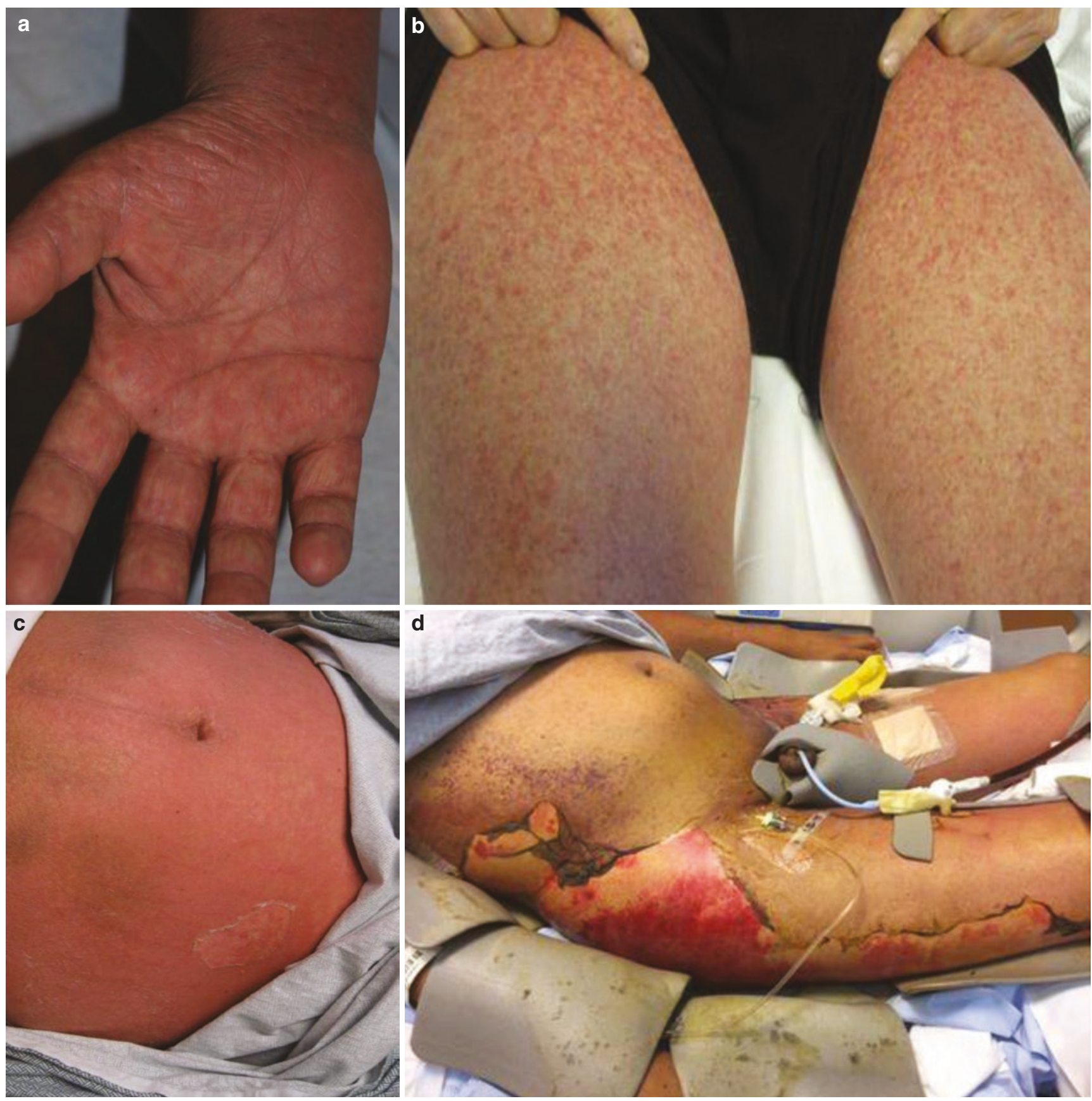

Fig. 80.1 Cutaneous Manifestations of Acute Graft-Versus-Host Disease. From [72], with permission . (a) Palmar erythema with microvesicles. (b) Morbilliform lesions on thighs. (c) Confluent ery-

thema with scale mimicking staphylococcal scalded skin syndrome. (d) Erythema with sheet-like desquamation mimicking toxic epidermal necrolysis

autoimmune disease [75]. While diagnostic criteria include effects on the skin, oral mucosa, eyes, liver, GI tract, joints, genitals, and lungs, chronic GVHD can affect almost any organ system and is staged according to severity of organ involvement [78]. Selected manifestations and diagnostic criteria are in Table 80.4. Of the manifestations of chronic GVHD, the most relevant to the ICU physician is pulmonary chronic GVHD.

\section{Pulmonary Chronic GVHD}

The only recognized manifestation of chronic pulmonary GVHD is bronchiolitis obliterans syndrome (BOS), which is diagnosed by documentation of the new onset of an obstructive ventilator defect $\left(\mathrm{FEV}_{1}: \mathrm{FVC}<0.7\right.$ and $\mathrm{FEV}_{1}<75 \%$ predicted) and air trapping (documented by expiratory $\mathrm{CT}$ scan or pulmonary function tests) in the absence of an explanatory pulmonary infection [78]. BOS results from 
Table 80.3 Manifestations and grading of acute graft-vs-host disease

\begin{tabular}{|c|c|c|}
\hline Organ site & Manifestation & Grading \\
\hline Skin & $\begin{array}{l}\text { Erythema } \\
\text { Maculopapular } \\
\text { rash } \\
\text { Blisters/ } \\
\text { ulceration } \\
\text { Desquamation }\end{array}$ & $\begin{array}{l}\text { Stage 0: No rash } \\
\text { Stage 1: Maculopapular rash, < } \\
25 \% \text { BSA } \\
\text { Stage 2: Maculopapular rash, } \\
\text { 25-50\% BSA } \\
\text { Stage 3: Maculopapular rash, } \\
>50 \% \text { BSA } \\
\text { Stage 4: Erythroedema } \\
\text { (>50\%) + bullae and } \\
\text { Desquamation }>5 \% \text { BSA }\end{array}$ \\
\hline $\begin{array}{l}\text { Gastrointestinal } \\
\text { tract }\end{array}$ & $\begin{array}{l}\text { Anorexia } \\
\text { Nausea, } \\
\text { vomiting } \\
\text { Diarrhea } \\
\text { Abdominal pain } \\
\text { Ileus } \\
\text { Bloody diarrhea }\end{array}$ & $\begin{array}{l}\text { Stage 0: No nausea, vomiting, } \\
\text { anorexia; } \\
\text { Diarrhea }<500 \mathrm{~mL} / \text { day } \\
\text { Stage 1: Persistent nausea, } \\
\text { vomiting, anorexia; } \\
\text { Diarrhea } 500-999 \mathrm{~mL} / \text { day } \\
\text { Stage } 2 \text { : Diarrhea } 1000- \\
1500 \mathrm{~mL} / \text { day } \\
\text { Stage } 3 \text { : Diarrhea }>1500 \mathrm{~mL} / \text { day } \\
\text { Stage } 4 \text { : Severe pain or grossly } \\
\text { bloody stool }\end{array}$ \\
\hline Liver & $\begin{array}{l}\text { Elevated } \\
\text { bilirubin } \\
\text { Cholestasis }\end{array}$ & $\begin{array}{l}\text { Stage 0: Bilirubin }<2 \mathrm{mg} / \mathrm{dL} \\
\text { Stage 1: Bilirubin } 2-3 \mathrm{mg} / \mathrm{dL} \\
\text { Stage 2: Bilirubin } 3.1-6 \mathrm{mg} / \mathrm{dL} \\
\text { Stage 3: Bilirubin } 6.1-15 \mathrm{mg} / \mathrm{dL} \\
\text { Stage 4: Bilirubin }>15 \mathrm{mg} / \mathrm{dL}\end{array}$ \\
\hline
\end{tabular}

BSA body surface area; Refs: [69-71] peribronchiolar fibrosis and obliteration of small airways resulting in the characteristic obstructive physiology [75]. Interstitial and subpleural fibrosis may also occur, resulting in concomitant restrictive physiology. BOS occurs in approximately 3-5\% of all patients after allogeneic HSCT, and 14\% of those with chronic GVHD, but is likely underdiagnosed [76, 79, 80]. Inhaled corticosteroids appear efficacious in improving $\mathrm{FEV}_{1}$ in established BOS [81]. Systemic steroids are also commonly used to treat BOS and most patients are maintained on anti-GVHD immunosuppression with tacrolimus, sirolimus, or a calcineurin inhibitor [76]. The combination of inhaled fluticasone, azithromycin, and montelukast (FAM) appears to slow the decline in lung function with BOS [82] but has not yet been proven in a randomized controlled trial. While FAM is standard therapy for established BOS, recent data argue strongly against using azithromycin as prophylaxis against BOS due to decreased survival due to a higher rate of hematologic relapse [83]. Though FAM has been shown to decrease the progression of BOS, mortality due to progressive lung disease remains high, and patients typically present to the ICU with respiratory failure. Unfortunately, with end-stage BOS, there are no effective therapeutic options. A select few patients may be eligible for consideration for lung transplantation, but this is unusual,

Table 80.4 Typical manifestations and grading of chronic graft-vs-host disease [78]

\begin{tabular}{|c|c|c|}
\hline Organ site & Manifestations & Grading \\
\hline Skin & $\begin{array}{l}\text { Poikiloderma }^{\mathrm{a}} \\
\text { Lichen planus-like changes }^{\mathrm{a}} \\
\text { Dermatosclerosis }^{\mathrm{a}} \\
\text { Erythema } \\
\text { Maculopapular rash } \\
\text { Depigmentation } \\
\text { Papulosquamous lesions } \\
\text { Hair loss }\end{array}$ & $\begin{array}{l}\text { Score 0: No skin involvement } \\
\text { Score 1: 1-18\% BSA } \\
\text { Score 2: } 19-50 \% \text { BSA; superficial sclerosis } \\
\text { Score 3: > 50\% BSA; deep sclerosis, ulceration, impaired mobility }\end{array}$ \\
\hline Oral mucosa & $\begin{array}{l}\text { Lichen planus-like changes }^{\mathrm{a}} \\
\text { Gingivitis } \\
\text { Mucositis } \\
\text { Erythema } \\
\text { Pain } \\
\text { Oral ulcers } \\
\text { Xerostomia } \\
\text { Pseudomembranes }\end{array}$ & $\begin{array}{l}\text { Score 0: No oral symptoms } \\
\text { Score 1: No limitation on oral intake } \\
\text { Score 2: Partial limitation on oral intake } \\
\text { Score 3: Major limitation on oral intake }\end{array}$ \\
\hline Eyes & Keratoconjunctivitis sicca & $\begin{array}{l}\text { Score 0: No symptoms } \\
\text { Score 1: No effect on ADL } \\
\text { Score 2: Moderate effect on ADL, no vision impairment } \\
\text { Score 3: Significant effect on ADL, or loss of vision }\end{array}$ \\
\hline GI tract & $\begin{array}{l}\text { Esophageal web }^{\mathrm{a}} \\
\text { Esophageal strictures }^{\mathrm{a}} \\
\text { Anorexia } \\
\text { Nausea/vomiting } \\
\text { Diarrhea } \\
\text { Elevated bilirubin/ALT/Alk Phos }\end{array}$ & $\begin{array}{l}\text { Score 0: No symptoms, normal bilirubin, normal ALT, normal Alk Phos } \\
\text { Score 1: No weight loss, normal bilirubin, ALT 3-5x ULN, Alk Phos }>3 \mathrm{x} \\
\text { ULN } \\
\text { Score 2: Weight loss }(5-15 \%) \text {, moderate diarrhea, bilirubin }<3 \mathrm{mg} / \mathrm{dL} \text {, ALT } \\
>5 \mathrm{x} \text { ULN } \\
\text { Score } 3 \text { : Weight loss }>15 \% \text { or need for esophageal dilation or severe } \\
\text { diarrhea or bilirubin }>3 \mathrm{mg} / \mathrm{dL}\end{array}$ \\
\hline Lungs & 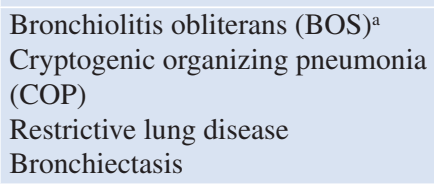 & $\begin{array}{l}\text { Score 0: No symptoms, } \mathrm{FEV}_{1} \geq 80 \% \\
\text { Score 1: Mild symptoms; } \mathrm{FEV}_{1} 60-79 \% \\
\text { Score 2: Moderate symptoms; } \mathrm{FEV}_{1} 40-59 \% \\
\text { Score 3: Short of breath at rest, } \mathrm{O}_{2} \text { requirement, } \mathrm{FEV}_{1} \leq 39 \%\end{array}$ \\
\hline
\end{tabular}


Table 80.4 (continued)

\begin{tabular}{|c|c|c|}
\hline Organ site & Manifestations & Grad \\
\hline Connective tissue & $\begin{array}{l}\text { Fasciitis }^{\mathrm{a}} \\
\text { Joint stiffness/contractures }^{\text {a }} \\
\text { Myositis } \\
\text { Arthralgias } \\
\text { Muscle cramps }\end{array}$ & \\
\hline Hematopoietic & $\begin{array}{l}\text { Cytopenias } \\
\text { Esoinophilia } \\
\text { Autoantibodies } \\
\text { Immunoglobulin deficiency }\end{array}$ & N/A \\
\hline Miscellaneous & $\begin{array}{l}\text { Reynaud's phenomenon } \\
\text { Pericardial/pleural effusions } \\
\text { Ascities } \\
\text { Peripheral neuropathy } \\
\text { Nephrotic syndrome } \\
\text { Cardiac conduction disturbance }\end{array}$ & N/A \\
\hline \multicolumn{3}{|c|}{$\begin{array}{l}{ }^{a} \text { Diagnostic of chronic GVHD; } B S A \text { body surface area, } A D L \text { activities o } \\
\text { tase, } U L N \text { upper limit of normal, ROM range of motion }\end{array}$} \\
\hline
\end{tabular}

\section{Evidence Contour}

HSCT is increasing in volume and importance as a therapeutic modality, and the volumes of HSCT patients requiring critical care is accordingly continuing to increase. There is good reason to think that the pathogenesis of critical illness is substantially different in the immunosuppressed HSCT patient. Yet our understanding of critical illness in this population is limited, and many practices are extrapolated from the general critical care population without direct evidence in the HSCT population. In response to this, research agendas for critically ill hematology and oncology patients have been proposed [48].

\section{Biology of Neutropenic Sepsis and Respiratory Failure}

Neutropenic sepsis is typically thought of as an uncontrolled variant of non-neutropenic sepsis. However, the real picture is likely much more complicated, and neutropenic sepsis and respiratory failure may be very different from their nonneutropenic counterparts. Even the phrase "neutropenic sepsis" is a misnomer, as the HSCT myelopreparative regimens also result in pancytopenia. Leukopenia, including neutropenia, lymphopenia, and monocytopenia, dramatically changes not only the acute response to infection, but the regulation of the adaptive immune response and the resolution and repair of injury [3, 7, 8, 84-90]. Platelets are increasingly recognized to play a vital role in the defense against bacterial, viral, and fungal infections, and like leukocytes, are integral to the development and resolution of organ failure [91-95]. Not surprisingly, thrombocytopenia is associated with poor outcomes in critical illness [96]. Taken together, these data strongly support the notion that common critical care conditions, such as sepsis and respiratory failure, may differ dramatically in HSCT patients compared to "normal" patients. Encouragingly, survival in neutropenic sepsis appears to be improving, but still lags that of non-neutropenic patients [12, $19,48]$, and more research is needed.

\section{Resistant and Multi-Drug Resistant Organisms}

Drug-resistant and multi-drug resistant (MDR) organisms are an increasing problem in HSCT patients, and the situation shows no sign of improving [16, 97, 98]. Vancomycinresistant enterococcus (VRE) bacteremia affects up to $35 \%$ of patients after HSCT and is associated with poor outcomes [99-101]. Similarly, MDR gram negative infections, particularly carbapenem-resistant Enterobacteriaceae (CRE), are associated with high mortality rates in allogeneic HSCT patients [102]. Successful treatment CRE infections is challenging, and requires early use of multi-drug antibiotic regimens, typically including aminoglycosides, carbepenems, and polymyxins. However, none of the available regimens are particularly effective, and new antimicrobials are desperately needed.

\section{Thrombotic Microangiopathy}

An increasingly recognized complication of HSCT is HSCTassociated thrombotic microangiopathy (HSCT-TMA) [103], which has some features in common with betterknown microangiopathic processes such as thrombotic 
thrombocytopenic purpura and atypical hemolytic uremic syndrome. HSCT-TMA occurs in a large number of patients post allogeneic HSCT (up to 20-40\%) and appears to be the result of endothelial injury and complement activation. Most occurrences are within the first 100 days after transplant. Patients can present to the ICU with acute kidney injury and neurologic changes in addition to hemolytic anemia and thrombocytopenia $[65,104]$. Management is predominantly supportive, with blood pressure control, cessation of any possible pharmacologic instigators (tacrolimus or cyclosporine), and renal replacement therapy playing major roles. Recent case reports have suggested a possible role in some patients for the anti-CD20 antibody rituximab or the anti-complement antibody eculizumab, though neither of these agents has been definitively proven effective [104].

\section{Cytokine Release Syndrome and Emerging Toxicities of Transplant}

As noted above, advances in transplant techniques have allowed the increased use of alternative donors, including related haploidentical donors [105-107]. Similarly, peripheral blood stem cells (PBSC) are increasingly used for transplant instead of bone marrow stem cells [108]. However, the use of peripheral blood results in a larger number of donor T-cells included in the transplanted stem cells. This higher T-cell dose can result in a profound syndrome of fevers, vascular permeability, hemodynamic instability, acute kidney injury, and respiratory failure. This constellation of findings is associated with elevated levels of inflammatory cytokines and has accordingly been labeled as cytokine release syndrome (CRS). While most associated with chimeric antigen receptor (CAR) T-cell therapy [109], CRS is increasing recognized after PBSC transplant and is associated with poor outcomes [110]. Emerging data suggest that anti-IL-6 therapy with tocilizumab may improve outcomes, but more research is needed [110].

\section{Organization of Critical Care: Need for Specialty Hematopoietic Stem Cell Transplant ICUs?}

HSCT continues to grow as a therapeutic modality and the pool of both potential donors and recipients continues to increase. As HSCT volumes increase and the complexity and potential toxicity of HSCT regimens expands, the number of critically ill HSCT patients will increase [48]. In response to this growing ICU volume, some centers continue to admit HSCT patients to general ICUs, but many high-volume transplant centers have developed specialty HSCT ICUs. While specialty HSCT ICUs have a number of potential benefits, there are few data to support (or dissuade) their development. Development of best practices for the provision of critical care to HSCT patients, including the optimum ICU organization is an important area for study [48]. Great progress in the critical care of HSCT patients has been made, but with continued basic and clinical research and further development of the sub-specialty of oncologic critical care, outcomes for critically ill HSCT patients should continue to improve.

\section{References}

1. D'Souza A, Fretham, C. Current Uses and Outcomes of Hematopoietic Cell Transplantation (HCT): CIBMTR Summary Slides, 2017. 2017.

2. Mauch P, Constine L, Greenberger J, Knospe W, Sullivan J, Liesveld JL, et al. Hematopoietic stem cell compartment: acute and late effects of radiation therapy and chemotherapy. Int J Radiat Oncol Biol Phys. 1995;31(5):1319-39.

3. Luan YY, Dong N, Xie M, Xiao XZ, Yao YM. The significance and regulatory mechanisms of innate immune cells in the development of sepsis. J Interferon Cytokine Res. 2014;34(1):2-15.

4. Blijlevens NM, Donnelly JP, De Pauw BE. Mucosal barrier injury: biology, pathology, clinical counterparts and consequences of intensive treatment for haematological malignancy: an overview. Bone Marrow Transplant. 2000;25(12):1269-78.

5. Blijlevens NM, Donnelly JP, DePauw BE. Inflammatory response to mucosal barrier injury after myeloablative therapy in allogeneic stem cell transplant recipients. Bone Marrow Transplant. 2005;36(8):703-7.

6. van der Velden WJ, Herbers AH, Netea MG, Blijlevens NM. Mucosal barrier injury, fever and infection in neutropenic patients with cancer: introducing the paradigm febrile mucositis. Br J Haematol. 2014;167(4):441-52.

7. Mokart D, Guery BP, Bouabdallah R, Martin C, Blache JL, Arnoulet C, et al. Deactivation of alveolar macrophages in septic neutropenic ARDS. Chest. 2003;124(2):644-52.

8. Mokart D, Kipnis E, Guerre-Berthelot P, Vey N, Capo C, Sannini $\mathrm{A}$, et al. Monocyte deactivation in neutropenic acute respiratory distress syndrome patients treated with granulocyte colonystimulating factor. Crit Care. 2008;12(1):R17.

9. Cordonnier C, Escudier E, Verra F, Brochard L, Bernaudin JF, Fleury-Feith J. Bronchoalveolar lavage during neutropenic episodes: diagnostic yield and cellular pattern. Eur Respir J. 1994;7(1):114-20.

10. Afessa B, Azoulay E. Critical care of the hematopoietic stem cell transplant recipient. Crit Care Clin. 2010;26(1):133-50.

11. Azoulay E, Mokart D, Pene F, Lambert J, Kouatchet A, Mayaux $\mathrm{J}$, et al. Outcomes of critically ill patients with hematologic malignancies: prospective multicenter data from France and Belgium--a groupe de recherche respiratoire en reanimation oncohematologique study. J Clin Oncol. 2013;31(22):2810-8.

12. Azoulay E, Pene F, Darmon M, Lengline E, Benoit D, Soares M, et al. Managing critically Ill hematology patients: Time to think differently. Blood Rev. 2015;29(6):359-67.

13. Saillard C, Darmon M, Bisbal M, Sannini A, Chow-Chine L, Faucher M, et al. Critically ill allogenic HSCT patients in the intensive care unit: a systematic review and meta-analysis of prognostic factors of mortality. Bone Marrow Transplant. 2018;53(10):1233-41.

14. Freifeld AG, Bow EJ, Sepkowitz KA, Boeckh MJ, Ito JI, Mullen $\mathrm{CA}$, et al. Clinical practice guideline for the use of antimicrobial 
agents in neutropenic patients with cancer: 2010 Update by the Infectious Diseases Society of America. Clin Infect Dis. 2011;52(4):427-31.

15. Heinz WJ, Buchheidt D, Christopeit M, von Lilienfeld-Toal M, Cornely OA, Einsele H, et al. Diagnosis and empirical treatment of fever of unknown origin (FUO) in adult neutropenic patients: guidelines of the Infectious Diseases Working Party (AGIHO) of the German Society of Hematology and Medical Oncology (DGHO). Ann Hematol. 2017;96(11):1775-92.

16. Montassier E, Batard E, Gastinne T, Potel G, de La Cochetiere MF. Recent changes in bacteremia in patients with cancer: a systematic review of epidemiology and antibiotic resistance. Eur J Clin Microbiol Infect Dis. 2013;32(7):841-50.

17. Trecarichi EM, Pagano L, Candoni A, Pastore D, Cattaneo C, Fanci R, et al. Current epidemiology and antimicrobial resistance data for bacterial bloodstream infections in patients with hematologic malignancies: an Italian multicentre prospective survey. Clin Microbiol Infect. 2015;21(4):337-43.

18. Kumar G, Ahmad S, Taneja A, Patel J, Guddati AK, Nanchal R, et al. Severe sepsis in hematopoietic stem cell transplant recipients*. Crit Care Med. 2015;43(2):411-21.

19. Legrand M, Max A, Peigne V, Mariotte E, Canet E, Debrumetz A, et al. Survival in neutropenic patients with severe sepsis or septic shock. Crit Care Med. 2012;40(1):43-9.

20. Mokart D, Darmon M, Resche-Rigon M, Lemiale V, Pene F, Mayaux J, et al. Prognosis of neutropenic patients admitted to the intensive care unit. Intensive Care Med. 2015;41(2):296-303.

21. Penack O, Becker C, Buchheidt D, Christopeit M, Kiehl M, von Lilienfeld-Toal $\mathrm{M}$, et al. Management of sepsis in neutropenic patients: 2014 updated guidelines from the Infectious Diseases Working Party of the German Society of Hematology and Medical Oncology (AGIHO). Ann Hematol. 2014;93(7): 1083-95.

22. Rosa RG, Goldani LZ. Cohort study of the impact of time to antibiotic administration on mortality in patients with febrile neutropenia. Antimicrob Agents Chemother. 2014;58(7):3799-803.

23. Rhodes A, Evans LE, Alhazzani W, Levy MM, Antonelli M, Ferrer R, et al. Surviving Sepsis Campaign: International Guidelines for Management of Sepsis and Septic Shock: 2016. Crit Care Med. 2017;45(3):486-552.

24. Paul M, Dickstein Y, Schlesinger A, Grozinsky-Glasberg S, Soares-Weiser K, Leibovici L. Beta-lactam versus beta-lactamaminoglycoside combination therapy in cancer patients with neutropenia. Cochrane Database Syst Rev. 2013;6:CD003038.

25. Paul M, Soares-Weiser K, Leibovici L. Beta lactam monotherapy versus beta lactam-aminoglycoside combination therapy for fever with neutropenia: systematic review and meta-analysis. BMJ. 2003;326(7399):1111.

26. Walsh TJ, Finberg RW, Arndt C, Hiemenz J, Schwartz C, Bodensteiner D, et al. Liposomal amphotericin B for empirical therapy in patients with persistent fever and neutropenia. National Institute of Allergy and Infectious Diseases Mycoses Study Group. N Engl J Med. 1999;340(10):764-71.

27. Walsh TJ, Teppler H, Donowitz GR, Maertens JA, Baden LR, Dmoszynska A, et al. Caspofungin versus liposomal amphotericin $B$ for empirical antifungal therapy in patients with persistent fever and neutropenia. N Engl J Med. 2004;351(14):1391-402.

28. Sachak T, Arnold MA, Naini BV, Graham RP, Shah SS, Cruise M, et al. Neutropenic enterocolitis: new insights into a deadly entity. Am J Surg Pathol. 2015;39(12):1635-42.

29. Saillard C, Zafrani L, Darmon M, Bisbal M, Chow-Chine L, Sannini A, et al. The prognostic impact of abdominal surgery in cancer patients with neutropenic enterocolitis: a systematic review and meta-analysis, on behalf the Groupe de Recherche en Reanimation Respiratoire du patient d'Onco-Hematologie (GRRR-OH). Ann Intensive Care. 2018;8(1):47.
30. Azoulay E, Lemiale V, Mokart D, Pene F, Kouatchet A, Perez P, et al. Acute respiratory distress syndrome in patients with malignancies. Intensive Care Med. 2014;40(8):1106-14.

31. Azoulay E, Darmon M. Acute respiratory distress syndrome during neutropenia recovery. Crit Care. 2010;14(1):114.

32. Soubani AO, Miller KB, Hassoun PM. Pulmonary complications of bone marrow transplantation. Chest. 1996;109(4):1066-77.

33. Allareddy V, Roy A, Rampa S, Lee MK, Nalliah RP, Allareddy V, et al. Outcomes of stem cell transplant patients with acute respiratory failure requiring mechanical ventilation in the United States. Bone Marrow Transplant. 2014;49(10):1278-86.

34. Yadav H, Nolan ME, Bohman JK, Cartin-Ceba R, Peters SG, Hogan WJ, et al. Epidemiology of acute respiratory distress syndrome following hematopoietic stem cell transplantation. Crit Care Med. 2016;44(6):1082-90.

35. Girmenia C, Martino P. Pulmonary infections complicating hematological disorders. Semin Respir Crit Care Med. 2005;26(5):445-57.

36. Jansen RR, Biemond BJ, Schinkel J, Koekkoek SM, Molenkamp $\mathrm{R}$, de Jong MD, et al. Febrile neutropenia: significance of elaborated screening for respiratory viruses, and the comparison of different sampling methods, in neutropenic patients with hematological malignancies. Virol J. 2013;10:212.

37. Vakil E, Evans SE. Viral pneumonia in patients with hematologic malignancy or hematopoietic stem cell transplantation. Clin Chest Med. 2017;38(1):97-111.

38. Renaud C, Xie H, Seo S, Kuypers J, Cent A, Corey L, et al. Mortality rates of human metapneumovirus and respiratory syncytial virus lower respiratory tract infections in hematopoietic cell transplantation recipients. Biol Blood Marrow Transplant. 2013;19(8):1220-6.

39. Dignan FL, Clark A, Aitken C, Gilleece M, Jayakar V, Krishnamurthy $\mathrm{P}$, et al. BCSH/BSBMT/UK clinical virology network guideline: diagnosis and management of common respiratory viral infections in patients undergoing treatment for haematological malignancies or stem cell transplantation. $\mathrm{Br} \mathrm{J}$ Haematol. 2016;173(3):380-93.

40. Shah JN, Chemaly RF. Management of RSV infections in adult recipients of hematopoietic stem cell transplantation. Blood. 2011;117(10):2755-63.

41. Chemaly RF, Shah DP, Boeckh MJ. Management of respiratory viral infections in hematopoietic cell transplant recipients and patients with hematologic malignancies. Clin Infect Dis. 2014;59(Suppl 5):S344-51.

42. Young AY, Leiva Juarez MM, Evans SE. Fungal pneumonia in patients with hematologic malignancy and hematopoietic stem cell transplantation. Clin Chest Med. 2017;38(3):479-91.

43. Acute Respiratory Distress Syndrome N, Brower RG, Matthay MA, Morris A, Schoenfeld D, Thompson BT, et al. Ventilation with lower tidal volumes as compared with traditional tidal volumes for acute lung injury and the acute respiratory distress syndrome. N Engl J Med. 2000;342(18):1301-8.

44. Papazian L, Forel JM, Gacouin A, Penot-Ragon C, Perrin G, Loundou A, et al. Neuromuscular blockers in early acute respiratory distress syndrome. N Engl J Med. 2010;363(12):1107-16.

45. Guerin C, Reignier J, Richard JC, Beuret P, Gacouin A, Boulain $\mathrm{T}$, et al. Prone positioning in severe acute respiratory distress syndrome. N Engl J Med. 2013;368(23):2159-68.

46. Cortegiani A, Madotto F, Gregoretti C, Bellani G, Laffey JG, Pham T, et al. Immunocompromised patients with acute respiratory distress syndrome: secondary analysis of the LUNG SAFE database. Crit Care. 2018;22(1):157.

47. Hilbert G, Gruson D, Vargas F, Valentino R, Gbikpi-Benissan G, Dupon $\mathrm{M}$, et al. Noninvasive ventilation in immunosuppressed patients with pulmonary infiltrates, fever, and acute respiratory failure. N Engl J Med. 2001;344(7):481-7. 
48. Azoulay E, Schellongowski P, Darmon M, Bauer PR, Benoit D, Depuydt $\mathrm{P}$, et al. The Intensive Care Medicine research agenda on critically ill oncology and hematology patients. Intensive Care Med. 2017;43(9):1366-82.

49. Carteaux G, Millan-Guilarte T, De Prost N, Razazi K, Abid S, Thille AW, et al. Failure of noninvasive ventilation for de novo acute hypoxemic respiratory failure: role of tidal volume. Crit Care Med. 2016;44(2):282-90.

50. Neuschwander A, Lemiale V, Darmon M, Pene F, Kouatchet A, Perez P, et al. Noninvasive ventilation during acute respiratory distress syndrome in patients with cancer: trends in use and outcome. J Crit Care. 2017;38:295-9.

51. Lemiale V, Mokart D, Resche-Rigon M, Pene F, Mayaux J, Faucher E, et al. Effect of noninvasive ventilation vs oxygen therapy on mortality among immunocompromised patients with acute respiratory failure: a randomized clinical trial. JAMA. 2015;314(16):1711-9.

52. Lemiale V, Resche-Rigon M, Mokart D, Pene F, Rabbat A, Kouatchet A, et al. Acute respiratory failure in patients with hematological malignancies: outcomes according to initial ventilation strategy. A groupe de recherche respiratoire en reanimation onco-hematologique (Grrr-OH) study. Ann Intensive Care. 2015;5(1):28.

53. Frat JP, Thille AW, Mercat A, Girault C, Ragot S, Perbet S, et al. High-Flow Oxygen through Nasal Cannula in Acute Hypoxemic Respiratory Failure. N Engl J Med. 2015;372(23):2185-96.

54. Azoulay E, Mokart D, Lambert J, Lemiale V, Rabbat A, Kouatchet A, et al. Diagnostic strategy for hematology and oncology patients with acute respiratory failure: randomized controlled trial. Am J Respir Crit Care Med. 2010;182(8):1038-46.

55. Azoulay E, Mokart D, Rabbat A, Pene F, Kouatchet A, Bruneel F, et al. Diagnostic bronchoscopy in hematology and oncology patients with acute respiratory failure: prospective multicenter data. Crit Care Med. 2008;36(1):100-7.

56. Gupta S, Jain A, Warneke CL, Gupta A, Shannon VR, Morice $\mathrm{RC}$, et al. Outcome of alveolar hemorrhage in hematopoietic stem cell transplant recipients. Bone Marrow Transplant. 2007;40(1): 71-8.

57. Rathi NK, Tanner AR, Dinh A, Dong W, Feng L, Ensor J, et al. Low-, medium- and high-dose steroids with or without aminocaproic acid in adult hematopoietic SCT patients with diffuse alveolar hemorrhage. Bone Marrow Transplant. 2015;50(3):420-6.

58. Panoskaltsis-Mortari A, Griese M, Madtes DK, Belperio JA, Haddad IY, Folz RJ, et al. An official American Thoracic Society research statement: noninfectious lung injury after hematopoietic stem cell transplantation: idiopathic pneumonia syndrome. Am J Respir Crit Care Med. 2011;183(9):1262-79.

59. Thompson J, Yin Z, D'Souza A, Fenske T, Hamadani M, Hari P, et al. Etanercept and corticosteroid therapy for the treatment of late-onset idiopathic pneumonia syndrome. Biol Blood Marrow Transplant. 2017;23(11):1955-60.

60. Tizon R, Frey N, Heitjan DF, Tan KS, Goldstein SC, Hexner EO, et al. High-dose corticosteroids with or without etanercept for the treatment of idiopathic pneumonia syndrome after allo-SCT. Bone Marrow Transplant. 2012;47(10):1332-7.

61. Yanik GA, Grupp SA, Pulsipher MA, Levine JE, Schultz KR, Wall DA, et al. TNF-receptor inhibitor therapy for the treatment of children with idiopathic pneumonia syndrome. A joint Pediatric Blood and Marrow Transplant Consortium and Children's Oncology Group Study (ASCT0521). Biol Blood Marrow Transplant. 2015;21(1):67-73.

62. Yanik GA, Ho VT, Levine JE, White ES, Braun T, Antin JH, et al. The impact of soluble tumor necrosis factor receptor etanercept on the treatment of idiopathic pneumonia syndrome after allogeneic hematopoietic stem cell transplantation. Blood. 2008;112(8):3073-81.
63. Yanik GA, Horowitz MM, Weisdorf DJ, Logan BR, Ho VT, Soiffer RJ, et al. Randomized, double-blind, placebo-controlled trial of soluble tumor necrosis factor receptor: enbrel (etanercept) for the treatment of idiopathic pneumonia syndrome after allogeneic stem cell transplantation: blood and marrow transplant clinical trials network protocol. Biol Blood Marrow Transplant. 2014;20(6):858-64.

64. Benz R, Schanz U, Maggiorini M, Seebach JD, Stussi G. Risk factors for ICU admission and ICU survival after allogeneic hematopoietic SCT. Bone Marrow Transplant. 2014;49(1):62-5.

65. Sedhom R, Sedhom D, Jaimes E. Mini-review of kidney disease following hematopoietic stem cell transplant. Clin Nephrol. 2018;89(6):389-402.

66. Liu H, Li YF, Liu BC, Ding JH, Chen BA, Xu WL, et al. A multicenter, retrospective study of acute kidney injury in adult patients with nonmyeloablative hematopoietic SCT. Bone Marrow Transplant. 2010;45(1):153-8.

67. Dalle JH, Giralt SA. Hepatic veno-occlusive disease after hematopoietic stem cell transplantation: risk factors and stratification, prophylaxis, and treatment. Biol Blood Marrow Transplant. 2016;22(3):400-9.

68. Jones RJ, Lee KS, Beschorner WE, Vogel VG, Grochow LB, Braine HG, et al. Venoocclusive disease of the liver following bone marrow transplantation. Transplantation. 1987;44(6):778-83.

69. Zeiser R, Blazar BR. Acute graft-versus-host disease - biologic process, prevention, and therapy. $N$ Engl $\mathrm{J}$ Med. 2017;377(22):2167-79.

70. Ferrara JL, Levine JE, Reddy P, Holler E. Graft-versus-host disease. Lancet. 2009;373(9674):1550-61.

71. Harris AC, Young R, Devine S, Hogan WJ, Ayuk F, Bunworasate $\mathrm{U}$, et al. International, multicenter standardization of acute graftversus-host disease clinical data collection: a report from the Mount Sinai Acute GVHD International Consortium. Biol Blood Marrow Transplant. 2016;22(1):4-10.

72. Cotliar JA. Clinical presentation of acute cutaneous graft-versushost disease. In: Cotliar JA, editor. Atlas of graft-versus-host disease: approaches to diagnosis and treatment. Cham: Springer International Publishing; 2017. p. 21-8.

73. Khoury HJ, Wang T, Hemmer MT, Couriel D, Alousi A, Cutler C, et al. Improved survival after acute graft-versus-host disease diagnosis in the modern era. Haematologica. 2017;102(5):958-66.

74. Luznik L, Bolanos-Meade J, Zahurak M, Chen AR, Smith BD, Brodsky R, et al. High-dose cyclophosphamide as single-agent, short-course prophylaxis of graft-versus-host disease. Blood. 2010;115(16):3224-30.

75. Cooke KR, Luznik L, Sarantopoulos S, Hakim FT, Jagasia M, Fowler DH, et al. The biology of chronic graft-versus-host disease: a task force report from the National Institutes of Health Consensus Development Project on Criteria for Clinical Trials in Chronic Graft-versus-Host Disease. Biol Blood Marrow Transplant. 2017;23(2):211-34.

76. Arora M, Cutler CS, Jagasia MH, Pidala J, Chai X, Martin PJ, et al. Late acute and chronic graft-versus-host disease after allogeneic hematopoietic cell transplantation. Biol Blood Marrow Transplant. 2016;22(3):449-55.

77. Zeiser R, Blazar BR. Pathophysiology of chronic graftversus-host disease and therapeutic targets. N Engl J Med. 2017;377(26):2565-79.

78. Jagasia MH, Greinix HT, Arora M, Williams KM, Wolff D, Cowen EW, et al. National Institutes of Health Consensus Development Project on Criteria for Clinical Trials in Chronic Graft-versusHost Disease: I. The 2014 Diagnosis and Staging Working Group report. Biol Blood Marrow Transplant. 2015;21(3):389-401. e1

79. Chien JW, Duncan S, Williams KM, Pavletic SZ. Bronchiolitis obliterans syndrome after allogeneic hematopoietic stem cell transplantation-an increasingly recognized manifestation of 
chronic graft-versus-host disease. Biol Blood Marrow Transplant. 2010;16(1 Suppl):S106-14.

80. Au BK, Au MA, Chien JW. Bronchiolitis obliterans syndrome epidemiology after allogeneic hematopoietic cell transplantation. Biol Blood Marrow Transplant. 2011;17(7):1072-8.

81. Bergeron A, Chevret S, Chagnon K, Godet C, Bergot E, Peffault de Latour R, et al. Budesonide/Formoterol for bronchiolitis obliterans after hematopoietic stem cell transplantation. Am J Respir Crit Care Med. 2015;191(11):1242-9.

82. Williams KM, Cheng GS, Pusic I, Jagasia M, Burns L, Ho VT, et al. Fluticasone, azithromycin, and montelukast treatment for new-onset bronchiolitis obliterans syndrome after hematopoietic cell transplantation. Biol Blood Marrow Transplant. 2016;22(4):710-6.

83. Bergeron A, Chevret S, Granata A, Chevallier P, Vincent L, Huynh A, et al. Effect of azithromycin on airflow decline-free survival after allogeneic hematopoietic stem cell transplant: the ALLOZITHRO randomized clinical trial. JAMA. 2017;318(6):557-66.

84. McDonald B. Neutrophils in critical illness. Cell Tissue Res. 2018:371(3):607-15.

85. Kolaczkowska E, Kubes P. Neutrophil recruitment and function in health and inflammation. Nat Rev Immunol. 2013;13(3): 159-75.

86. Blazquez-Prieto J, Lopez-Alonso I, Amado-Rodriguez L, Huidobro C, Gonzalez-Lopez A, Kuebler WM, et al. Impaired lung repair during neutropenia can be reverted by matrix metalloproteinase-9. Thorax. 2018;73(4):321-30.

87. Leliefeld PH, Wessels CM, Leenen LP, Koenderman L, Pillay $\mathrm{J}$. The role of neutrophils in immune dysfunction during severe inflammation. Crit Care. 2016;20:73.

88. Tak T, Rygiel TP, Karnam G, Bastian OW, Boon L, Viveen M, et al. Neutrophil-mediated suppression of influenza-induced pathology requires CD11b/CD18 (MAC-1). Am J Respir Cell Mol Biol. 2018;58(4):492-9.

89. de Pablo R, Monserrat J, Prieto A, Alvarez-Mon M. Role of circulating lymphocytes in patients with sepsis. Biomed Res Int. 2014;2014:671087.

90. Reilly JP, Anderson BJ, Hudock KM, Dunn TG, Kazi A, Tommasini A, et al. Neutropenic sepsis is associated with distinct clinical and biological characteristics: a cohort study of severe sepsis. Crit Care. 2016;20(1):222.

91. Clark SR, Ma AC, Tavener SA, McDonald B, Goodarzi Z, Kelly MM, et al. Platelet TLR4 activates neutrophil extracellular traps to ensnare bacteria in septic blood. Nat Med. 2007;13(4):463-9.

92. Dewitte A, Lepreux S, Villeneuve J, Rigothier C, Combe C, Ouattara A, et al. Blood platelets and sepsis pathophysiology: a new therapeutic prospect in critical ill patients? Ann Intensive Care. 2017;7(1):115.

93. de Stoppelaar SF, van't Veer C, Claushuis TAM, Albersen BJA, Roelofs JJTH, van der Poll T. Thrombocytopenia impairs host defense in gram-negative pneumonia-derived sepsis in mice. Blood. 2014;124(25):3781-90.

94. Middleton EA, Weyrich AS, Zimmerman GA. Platelets in pulmonary immune responses and inflammatory lung diseases. Physiol Rev. 2016;96(4):1211-59.

95. Stocker TJ, Ishikawa-Ankerhold H, Massberg S, Schulz C. Small but mighty: Platelets as central effectors of host defense. Thromb Haemost. 2017;117(4):651-61.

96. Claushuis TA, van Vught LA, Scicluna BP, Wiewel MA, Klein Klouwenberg PM, Hoogendijk AJ, et al. Thrombocytopenia is associated with a dysregulated host response in critically ill sepsis patients. Blood. 2016;127(24):3062-72.
97. Freifeld AG, Bow EJ, Sepkowitz KA, Boeckh MJ, Ito JI, Mullen $\mathrm{CA}$, et al. Clinical practice guideline for the use of antimicrobial agents in neutropenic patients with cancer: 2010 update by the infectious diseases society of america. Clin Infect Dis. 2011;52(4):e56-93.

98. Forcina A, Lorentino F, Marasco V, Oltolini C, Marcatti M, Greco $\mathrm{R}$, et al. Clinical impact of pretransplant multidrug-resistant gramnegative colonization in autologous and allogeneic hematopoietic stem cell transplantation. Biol Blood Marrow Transplant. 2018 24:1476-1482.

99. Ornstein MC, Mukherjee S, Keng M, Elson P, Tiu RV, Saunthararajah Y, et al. Impact of vancomycin-resistant enterococcal bacteremia on outcome during acute myeloid leukemia induction therapy. Leuk Lymphoma. 2015;56(9):2536-42.

100. Weinstock DM, Conlon M, Iovino C, Aubrey T, Gudiol C, Riedel $\mathrm{E}$, et al. Colonization, bloodstream infection, and mortality caused by vancomycin-resistant enterococcus early after allogeneic hematopoietic stem cell transplant. Biol Blood Marrow Transplant. 2007;13(5):615-21.

101. Avery R, Kalaycio M, Pohlman B, Sobecks R, Kuczkowski E, Andresen S, et al. Early vancomycin-resistant enterococcus (VRE) bacteremia after allogeneic bone marrow transplantation is associated with a rapidly deteriorating clinical course. Bone Marrow Transplant. 2005;35(5):497-9.

102. Satlin MJ, Jenkins SG, Walsh TJ. The global challenge of carbapenem-resistant Enterobacteriaceae in transplant recipients and patients with hematologic malignancies. Clin Infect Dis. 2014;58(9):1274-83.

103. Wanchoo R, Bayer RL, Bassil C, Jhaveri KD. Emerging concepts in hematopoietic stem cell transplantation-associated renal thrombotic microangiopathy and prospects for new treatments. Am J Kidney Dis. 2018;72:857-65.

104. Elsallabi O, Bhatt VR, Dhakal P, Foster KW, Tendulkar KK. Hematopoietic stem cell transplant-associated thrombotic microangiopathy. Clin Appl Thromb Hemost. 2016;22(1):12-20.

105. Kanakry JA, Kasamon YL, Gocke CD, Tsai HL, Davis-Sproul J, Ghosh N, et al. Outcomes of related donor HLA-identical or HLA-haploidentical allogeneic blood or marrow transplantation for peripheral T cell lymphoma. Biol Blood Marrow Transplant. 2013;19(4):602-6.

106. Kasamon YL, Bolanos-Meade J, Prince GT, Tsai HL, McCurdy SR, Kanakry JA, et al. Outcomes of nonmyeloablative HLAhaploidentical blood or marrow transplantation with high-dose post-transplantation cyclophosphamide in older adults. J Clin Oncol. 2015;33(28):3152-61.

107. Luznik L, O'Donnell PV, Symons HJ, Chen AR, Leffell MS, Zahurak M, et al. HLA-haploidentical bone marrow transplantation for hematologic malignancies using nonmyeloablative conditioning and high-dose, posttransplantation cyclophosphamide. Biol Blood Marrow Transplant. 2008;14(6):641-50.

108. Anasetti C, Logan BR, Lee SJ, Waller EK, Weisdorf DJ, Wingard JR, et al. Peripheral-blood stem cells versus bone marrow from unrelated donors. N Engl J Med. 2012;367(16):1487-96.

109. Gutierrez C, McEvoy C, Mead E, Stephens RS, Munshi L, Detsky ME, et al. Management of the critically ill adult chimeric antigen Receptor-T cell therapy patient: a critical care perspective. Crit Care Med. 2018;46(9):1402-10.

110. Abboud R, Keller J, Slade M, DiPersio JF, Westervelt P, Rettig $\mathrm{MP}$, et al. Severe cytokine-release syndrome after T cell-replete peripheral blood haploidentical donor transplantation is associated with poor survival and Anti-IL-6 therapy is safe and well tolerated. Biol Blood Marrow Transplant. 2016;22(10):1851-60. 